\title{
From Shacks to Skyscrapers: Multiple Spatial Rationalities and Urban Transformation in Accra, Ghana
}

\author{
Lena Fält ${ }^{1}$ (D)
}

Published online: 9 November 2016

C The Author(s) 2016. This article is published with open access at Springerlink.com

\begin{abstract}
Recent studies indicate that market-driven logics increasingly inform the governing of African cities. This paper explores this claim by analysing the spatial rationalities at work in the struggle over urban space in Accra, Ghana. Based on an in-depth case study of a state-led displacement of a marginalised informal settlement in central Accra that took place in September 2014, the paper demonstrates that the on-going urban transformation of this city must be understood as an outcome of multiple spatial rationalities rooted in the local urban history but also influenced by globally circulating urban ideals. While a market-driven rationality is clearly present in the state's justification of the eviction, also 'generative' and 'dispositional' rationalities are used to legitimise this urban intervention. The paper further illustrates the conflicting rationalities between the state and the urban poor, emphasising how the former residents of the displaced settlement perceive of their former home as a place of opportunities in terms of livelihood strategies, sociability and affordable housing in contrast to the state's problematisation of the area.
\end{abstract}

Keywords Spatial rationalities - Speculative urbanism - Urban revanchism ·

Displacement · Urban planning · Accra

\section{Introduction}

African cities are growing and transforming at an unprecedented speed, and recent research suggests that market-driven rationalities increasingly inform city administrations' endeavours to organise and manage urban space (Myers 2015; Watson 2014). Economic growth and narratives of the 'rise of Africa' are creating optimism about the continent's urban future, and city authorities increasingly aspire to make their cities 'globally

Lena Fält

lena.falt@humangeo.su.se

1 Department of Human Geography, Stockholm University, Stockholm, Sweden 
competitive' (Ibid.). These aspirations are manifested through large-scale redevelopment projects that seek to 'modernise' entire city districts - both centrally located and at the urban fringes - and attempt to build entirely new cities (Miraftab 2007; Myers 2015; Parnell and Robinson 2006; Van Synghel and de Boeck 2013; Watson 2014). The construction of luxury condominiums, shopping malls and high-class tourism facilities also adds to recent attempts by city administrations to put their cities 'on the map' and thereby attract foreign investment and tourists (Pieterse 2008; Watson 2009a). Likewise, efforts to formalise and/or demolish informal settlements, the removal of (informal) street vendors from public spaces and the construction of symbolic 'world-class' buildings add to contemporary practices of urban restructuring that are at least partly informed by new urban aspirations (Ibid.). Watson (2014) argues that these trends must be understood as aspects of a new urban agenda where land speculation increasingly guides urban planning and states that 'processes of speculative urbanism /.../ are beginning to make an appearance on the African continent' (p. 2). To her, this new direction of urban development is likely to increase spatial and social inequality, and she predicts that ' $[\mathrm{s}]$ tate spending on large-scale infrastructure (transport, sanitation, power) is likely to be skewed in the direction of support for these new cities and projects and away from meeting the basic services and housing needs of the much larger poor urban populations' (Ibid. 15). In a similar vein, the concept 'urban revanchism' seeks to explain how urban politics driven by market-logics and anti-poor attitudes and aesthetics result in (new) patterns of sociospatial segregation - both in the global South and North (Smith 2001; Mackie et al. 2014; Swanson 2007; Turner and Schoenberger 2012). In Africa, however, empirical research on the logics and rationalities behind contemporary urban (re)development initiatives is still limited, and the role of speculative and revanchist practices is hence rather unclear. To gain a better understanding of recent trends of urban transformation across the African context, there is a need for more empirically grounded research.

In this paper, I therefore explore the spatial rationalities that inform contemporary processes of physical, social and economic restructuring in the rapidly transforming city of Accra, Ghana, and further elaborate on the explanatory power of 'speculative urbanism' and urban revanchism in this West African context. I approach this task through an indepth case study of the forced eviction ${ }^{1}$ of an informal settlement named Mensah Guinea that took place in central Accra in September 2014. Forced evictions can be understood as 'extreme' planning interventions and are therefore highly informative of the political rationalities at play in their locales, since extreme cases 'often reveal more information because they activate more actors and more basic mechanisms in the situation studied' (Flyvbjerg 2006: 229f.). The case study builds upon data generated during two periods of fieldwork in Accra during 2015, adding up to 14 weeks, where I sought to understand (1) how and by whom the eviction was ordered, justified and performed; (2) how the residents perceived of the area before the eviction and how they were affected by, and reacted to, the intervention and (3) what reactions the eviction evoked in media and among civil society agents. Semi-structured interviews were conducted with 20 civil servants, politicians and traditional chiefs that work with urban development, most of them development and physical planners and some of them directly involved in the eviction exercise. To better

\footnotetext{
${ }^{1}$ The United Nations definition of a forced eviction: 'the permanent or temporary removal against their will of individuals, families and/or communities from the homes and/or land which they occupy, without the provision of, and access to, appropriate forms of legal or other protection' (United Nations 2014: 3).
} 
understand the local context of contemporary urban politics, I also engaged in participatory observation during public meetings, conferences and workshops related to urban development in Accra/Ghana. The findings from these interviews and observations have been triangulated with a text analysis of Ghana's national urban policy from 2012, planning legislation and Accra's development plan for 2014. Semi-structured interviews were also conducted with the local community leader of Mensah Guinea and 15 former residents who lost their homes in the demolition exercise. These interviews were further complemented with observations in the area where the settlement used to be located and its surroundings. I also interviewed representatives of six NGO's working with housing and/or livelihood issues in Ghana's 'informal settlements'. News articles related to the demolition of Mensah Guinea that were published in Ghana's two leading daily newspapers, Daily Graphic and Daily Guide, during September 2014 also add to the empirical data. My positionality as a female, white, European researcher undoubtedly influenced both the data that was generated during the fieldwork and my interpretation of the material (England 2006). By triangulating different types of data, including interviews with many different stakeholders, and by reflecting on different possible interpretations of the generated data together with my field assistants, I seek to present a nuanced analysis of the eviction of Mensah Guinea and the different actors' positions and viewpoints on the intervention.

The paper demonstrates that the on-going urban transformation of Accra must be understood as an outcome of multiple spatial rationalities rooted in the local urban history but also influenced by globally circulating urban ideals. A market-driven rationality is clearly present in the state's justification of the eviction of Mensah Guinea and to conceptualise the on-going transformation of Accra as revanchist and/or speculative urbanism opens up for important insights into the new role of (authoritarian) market-driven approaches in African urban (re)development interventions and how these approaches may result in increasing spatial and social inequality. However, this study also stresses that it is important to acknowledge that contemporary urban transformations are directed by other-non-market-driven-rationalities as well. Besides a strong market-driven urban agenda, the eviction of Mensah Guinea is legitimised based on specific, historically rooted, ideas on what counts as desirable (and undesirable) urban development where the benefits of 'spatial order' are emphasised together with ideas on how to protect public health through interventions in the physical environment. Hence, to better understand the driving forces of contemporary urban development in Africa, we must account for the multiplicity of competing as well as converging rationalities at play in the struggle over urban space. Further, this paper highlights the plurality of actors engaged in the process of (re)formulating and (re)negotiating what counts as desirable urban development, and it is emphasised that also the rationalities and acts of non-state actors must be included in the analysis of Africa's future urban development.

The rest of the paper is organised as follows: first, the concept of spatial rationalities is elaborated upon, followed by a discussion on the notions of speculative urbanism and urban revanchism. Thereafter, a historical review of urban planning and eviction policy in Ghana from colonial times until today is presented, followed by the case study of the displacement of the informal settlement Mensah Guinea which took place in September 2014. The case study is divided into two parts: first, I present the former residents' narratives on the settlement and elaborate on the multiple rationalities behind their 
decision to settle in this particular place. Secondly, the multiple justifications for the eviction brought forward by local and central government agencies are presented and scrutinised together with an analysis of the responses to the intervention by news media and civil society actors. The paper ends with a concluding note on the multiple rationalities and actors that were found to actively inform the displacement of Mensah Guinea and, perhaps more importantly, broader processes of (re)development in urban Ghana.

\section{Spatial Rationalities in Urban Africa}

In urban studies, the analytics of governmentality has proved useful for highlighting how both state and non-state actors engage in the multifaceted process of governing urban environments and populations through specific rationalities and techniques (Appadurai 2001; Flint 2002; Flyvbjerg 1998; Foucault 2007; Kamete 2013; Bakker et al. 2008; see also Rose and Miller 1992 on a more general note). Geographers have made important contributions to this field by demonstrating the importance of space in the analysis of the 'art of government'. Huxley (2008: 1647), for instance, explains that space 'is inseparable from government' because 'projects of government imagine spatial and environmental causalities, draw up plans and programmes that deploy spatial techniques, and aspire to produce spatially specific conducts, even as they provoke counterconducts and counterspaces'. In a similar vein, Elden (2007: 578) states that 'Territory is more than merely land, but a rendering of the emergent concept of "space" as a political category: owned, distributed, mapped, calculated, bordered, and controlled'. Hence, urban planning becomes a 'leading institution in the rationalisation of urban space' that reflects wider power relations in urban politics (Kamete 2013: 640, with reference to Boyer 1983). Kamete (2013) further explains how urban planning creates a normalisation of certain urban environments and conducts which works as a benchmark for all urban spaces, causing informal and poor neighbourhoods to be perceived as abnormalities, often with a strong immoral connotation (see also Rabinow 1989).

Drawing on the work of Foucault, Huxley (2006) develops the spatial dimension of governmentality by introducing the analytical concept of spatial rationalities, which refers to the socially constructed bodies of knowledge that inform policy and action related to the spatial organisation of the city by linking physical environments with the 'conduct of subjects'. By exposing and analysing the knowledge and norms that underpin spatial remaking of cities, the concept of spatial rationalities enables the unpacking and problematisation of taken for granted assumptions and practices that direct urban development (Ibid.). The analysis of spatial rationalities can thus help explain the 'conditions of a consensus or the pre-requisites of acceptance', by revealing authoritarian truth claims with regard to urban (re)development initiatives (Rose and Miller 1992: 175). Hence, this concept has potential to give insights into the various knowledge bases that underpin the contemporary rapid transformation of African cities.

At a general urban level, Watson (2009a) has depicted contemporary land use politics in Africa as a 'clash of rationalities', where the city authorities' aspirations to create 'modernity' and 'order' conflict with the urban poor's struggles to make ends meet. This conceptualisation captures the well-documented discrepancy between government visions and everyday life of the urban poor in Africa in general terms (Myers 
2015; Robinson 2006). However, this concept also tends to conceal the multiple, variated and differentiated rationalities and actors engaged in the constantly on-going process of urban transformation (see Lindell 2008; Pieterse 2010). Hence, in-depth studies of the actual rationalities behind this clash in different localities are much needed. Huxley $(2006,2007)$ identifies three spatial rationalities that historically have been used in the governing of urban environments: the dispositional, the generative and the vitalist rationalities. Despite its rigidity, this scheme of rationalities can assist in providing a deeper understanding of contemporary urban development and the clash of rationalities described above. The dispositional spatial rationality 'aims at drawing boundaries and producing order that will foster correct comportments' (Huxley 2006: 774). Geometrical order, beauty and cleanliness are main components of this rationality, and an orderly physical arrangement of the built environment is thus, in itself, the goal for planning that adopts this rationality. The generative spatial rationality, in contrast, draws on knowledge about 'medico-biological' connections between physical environments and people, and it seeks to create 'healthy' environments that 'generate selfperpetuating moral regimes of health, productive activity and propriety' (Ibid: 778). Lastly, the vitalist spatial rationality embraces a more holistic view on urban space and attempts to create 'synergies of the biological, the spatial, the social and the spiritual' (Ibid: 783). This rationality thus relies on several bodies of knowledge, combining social and physical science, and it aims towards the 'government of the social whole' (Ibid: 781). The goal is to reach 'higher stages of development' for humanity and/or the nation state, and the idea of the welfare state is grounded in vitalist spatial rationalities (Ibid: 782). Huxley's typology draws upon dominant historical planning practices in European cities; however, it is also useful in the analysis of spatial rationalities that inform urban development in contemporary Africa due to the strong colonial heritage embedded in most planning systems on the continent (see Kamete 2013; Njoh 2003; Watson 2009b). While colonial planning practice played out differently in different cities, it was generally motivated by modernistic ideas emphasising both aspirations of environments that could form 'healthy' and 'moral' populations and that conceive of spatial order as a goal in itself. Dispositional and generative rationalities, informed by a strong racist agenda, thus dominated planning practice in African cities during the colonial era and are still found in planning law, policy documents and practices across the continent today (Ibid.). It is important to notice however that economic considerations also had a strong impact on actual planning outcomes during the colonial era (Byerley forthcoming; Legg 2006).

\section{Speculative Urbanism and 'Revanchist Cities' in Africa?}

More recently, the impact of neoliberal spatial rationalities in urban development schemes has attracted much scholarly attention, and concepts such as speculative urbanism and urban revanchism have been introduced in attempts to explain new trends of urban transformation across the African continent. Following Goldman (2011), Watson (2014) suggests that a new spatial rationality based on land speculation has taken root in urban Africa. Originally, the concept of speculative urbanism sought to capture recent shifts of urban governance in Bangalore, India, where land speculation and dispossession have become the 'main business of government of today' in this city's ambition to become a world city (Goldman 2011: 555). As such, speculative 
urbanism is driven by what Harvey (2007) terms 'accumulation by dispossession', yet Goldman argues that new concepts are needed to better capture recent developments in the global South since the 'magnitude, speed, and the overarching aura of legitimacy of these new governance endeavours are important to note' (p. 575). According to Goldman, urban planning in India is heavily influenced by globally circulating ideals of the 'competitive city' and commodification of urban land now lies at the heart of planning practices. Speculative urbanism hence includes rent-seeking practices of state bodies, parastatals, private actors (the IT sector in particular) and individuals and often results in the displacement of land uses not perceived to be compatible with the world city image, such as informal settlements (Ibid.). On the basis of this, Goldman concludes that 'the exceptional rules of dispossession enacted in the name of worldcity making are creating a new art of "speculative government", new anxieties differentially experienced across class, community and place, while also redefining state relations, urban citizenship, rights and rules of access', and the result is increased urban inequality (Ibid.: 556).

A related concept that seeks to capture authoritarian state practices, informed by market logics, that result in processes of socio-spatial segregation is urban revanchism (Smith 2001, 2002). This concept refers to rent-seeking politics and policies that seek to discipline urban space 'so that the enhancement of a city's image is not compromised by the visible presence of those very marginalized groups' (MacLeod 2002: 602). The concept was coined by Neil Smith during the 1990s as a response to the implementation of a zero-tolerance policy in New York which sought to remove 'undesirable' behaviour from public spaces such as 'street peddling, panhandling, prostitution, squeegee cleaners, boom boxes, graffiti, public drinking, loud clubs, speeding cars, litter louts, public urination, street artists, and "dangerous mentally ill homeless people" (Smith 2001: 69). Smith, however, did not understand urban revanchism as a Western phenomenon but predicted that this type of urban politics would gain momentum across the globe:

The danger is that the New York model will, as in the 1970s, become the template for a global, postliberal revanchism that may exact revenge against different social groups in different places, doing so with differing intensities and taking quite different forms. (p.73)

In line with this statement, Swanson (2007) argued just a few years later that urban revanchism had 'headed South'. Efforts made by Quito's city administration to attract international tourism, inspired by New York's zero policy on 'undesirable' behaviour in public spaces, pushed marginalised groups out of the city, and to Swanson this was 'a vengeful, right-wing reaction against the poor' brought forward by the dominant classes in an attempt to 'tame the wild city' (2007: 709). Research on contemporary African urban development, and the underlying rationalities of recently adopted policies and politics, is however limited, and the usefulness of the concepts above are not well investigated in this context. Thus, in order to gain a better understanding of contemporary and future directions of urban development, more research is needed and an important area of study is the underlying knowledge and norms that different, often competing, urban agendas rely upon. The rest of the paper is devoted to such an analysis, with focus on urban development in Accra, the capital of Ghana. 


\section{Accra's Planning and Eviction Policy in a Historical Perspective}

Evictions of informal settlements are not a new phenomenon in urban Ghana, but have taken place regularly since the colonial period with support from legal frameworks that guide urban land use (Larbi et al. 2004). The first law directing town planning in Ghana was passed by the British colonial administration in 1892 and updated 2 years later with regard to larger urban agglomerations (Dickson 1969: 265). This legislation, the Towns Ordinance, enabled the colonial government to acquire land for public works, to collect taxes, and to intervene in urban communities to improve the health and sanitary situation (Ibid). Furthermore, physical planning was seen as a means to 'order and regulate the environment' in accordance with the 'self-appointed mission of the colonialists in "civilizing” the natives' (Konadu-Agyemang 2001:138). In Accra, on the basis of these generative and dispositional rationalities - that emphasise the links between the physical environment and conceived health/moral risks and an orderly physical environment, respectively — several unplanned native areas were 'cleared' by the colonial administration in its attempts to modernise and reorganise urban space (Dickson 1969: 299).

In 1945, the colonial administration strengthened the legal framework for planning and the Town and Country Planning Act (Cap 84) was introduced. This law, which is still in place, explicitly provides for 'slum clearance in specified areas' and demolition of buildings 'which are inconsistent with or obstruct the operation of a scheme' (Government of Ghana 1945: 2). It was also during the 1940s that Accra got its first master plan and an updated version, 'Accra: A plan for the Town', was passed in 1958 by the newly independent state administration of Ghana (although designed by the former colonial administration) (Larbi 1996). This document '...had all the features of a master plan in terms of detail, site specificity and inflexibility' (Ibid.: 199), and as such, it contained a strong dispositional spatial rationality. The waterfront area where the community of Mensah Guinea was located is referred to as 'the Marine Drive' in this plan and was envisioned as a future place for leisure and tourism (Government of Ghana, Ministry of Housing 1958). However, the plan for the Marine Drive was never implemented. After independence in 1957, focus in planning circles changed from urban development to (socio-)economic development of the nation state (Larbi 1996) and hence dispositional rationalities - that emphasise spatial order in the cities - were downplayed while vitalist rationalities - focusing on developing the nation and its people - increasingly informed public debate. Larbi (1996) explains that during the 1960s and 1970s, 'land-use planning and [physical] development control were in essence non-existent' (p. 195). This statement is confirmed by three interviewed retired planners who describe Accra's physical planning office as heavily under-resourced during the first decades after independence (Interviews 2015), which suggests that development control and evictions were not a common phenomenon during this time period.

In 1992, a new constitution was introduced and it underscores the right to property ownership, but does not cater for more general housing rights (Mohindra and Schreker 2012). A year later, the Local Government Act (Act 462) was passed, and with regard to evictions, this law replicates the Town and Country Planning Law from 1945 and ensures that physical development is not allowed 'without prior approval in the form of a written permit granted by the district planning authority' (Government of Ghana 1993: 49). The same law also states that the local authority has the right to "carry out the 
prohibition, abatement, alternation, removal or demolition' of unauthorised buildings; however, such interventions should be preceded by a written notice to the land owners (Ibid: 52). Yet, development control was still not a prioritised issue for Accra's administration during the 1990s. The Mayor who held office between 1994 and 1998 explains that the growing informal settlements of that time, including Mensah Guinea, were ignored by the local government since it was assumed that these populations eventually would 'move back' to the countryside where 'they belonged' (Interview 2015).

Today, physical planning and spatial order are once again understood to be crucial building blocks for progressive urban development in Ghana (Government of Ghana, Ministry of Local Government and Rural Development 2012; World Bank 2014). In Accra, this renewed emphasis on spatial order is manifested in the by-law passed in 2011 that prohibits unauthorised structures and petty trading in the city. Furthermore, 'Decongestion and Beautification of the City' make up one of seven focus areas in Accra's development plan for 2014, and as part of this agenda, the city seeks to 'continue with the removal of unauthorized structures and prevent reoccurrences within the city'; 'continue with the removal of traders and squatters operating on the streets' and 'continue with the prosecution of traders and residents who violate the AMA [Accra Metropolitan Assembly] by-laws on selling on pavements' (Accra Metropolitan Assembly 2014). During the last decade, several evictions have occurred and threats of evictions have also been issued in the capital (Afenah 2012), and it seems likely that this development is directly related to the new emphasis on spatial order in urban policy circuits.

Interestingly however, the agenda of spatial order is also accompanied with a strong commitment to improve the situation for the urban poor. Ghana presented its first national urban policy in 2012, and it seeks to take a comprehensive hold on cities and coherently guide future urban development across the nation. The aim is to

...promote a sustainable, spatially integrated and orderly development of urban settlements with adequate housing and services, efficient institutions, sound living and working environment for all people to support rapid socio-economic development of Ghana. (Government of Ghana and Ministry of Local Government and Rural Development 2012: 3)

Both spatial order and socio-economic development are emphasised in the aim, and it is stressed that the whole urban population should benefit from the improved urban condition. In the prologue, it is stated that

This National Urban Policy document makes a bold statement to promote socioeconomic development of Ghanaian urban centres - a development process which is all-inclusive and takes account of the needs of the disadvantaged and vulnerable groups. /... . ...it makes far reaching proposals in an Action Plan for implementation in order to arrest rising inequalities in socio-economic and spatial terms and advance towards sustainable development. (Ibid: 12, emphasis added)

The policy thus explicitly targets 'disadvantaged and vulnerable groups' and seeks to prevent socio-economic and spatial inequalities in cities, which indicates a new approach to informal settlements and poor neighbourhoods compared to the legal 
framework that criminalises the presence of urban informality. However, alongside the broad development agenda, the national urban policy also highlights the importance of physical planning and spatial order. To achieve spatial order is part of the aim of the policy (see citation above), and 'spatial dis-order' is defined as a 'fundamental problem' to Ghanaian cities (Ibid: 3). Thus, the policy seeks to '[e]nsure adoption and implementation/enforcement of ... planning standards, spatial development frameworks, structure plans, local plans and land use controls' (Ibid: 25), and in the case of Mensah Guinea, this strong dispositional rationality added to the multiple justifications of the eviction, as the following analysis will demonstrate.

\section{Stories from 'Down Town'}

Five months after the demolition, when I first visited the area where Mensah Guinea used to be located, I found that hundreds of people still lived in the area. Or, to be accurate, they had left Mensah Guinea and moved to 'Down Town': 'This place, here, is Down Town, we call here Down Town' as one of my respondents explains. While the area dubbed Mensah Guinea was situated on the plateau above the beach, Down Town is located literally on the beach and has now become the home for those who did not have any other place to move to after the demolition of their former homes in Mensah Guinea. In Down Town, provisional shelters constructed from wood and cartons have been built up on the beach, just a few metres from the sea, and everyday life has become a struggle to make ends meet in a place where electricity, piped water, drainage, sanitation facilities and social services are absent (Fig. 1).

According to the respondents, the area of Mensah Guinea has been inhabited by the Ga people since the late eighteenth century when a family named Mensah Guinea decided to move a few kilometres from the old township Ga Mashie to the beach area between Ga Mashie and the next township Osu. This in-between location was then undeveloped but attractive because of its good fishing waters. After independence, the local government of Accra issued building permits for several houses used for residential and fishing activities in the area. Still, today the Mensah Guinea family holds papers that confirm their rights to occupy the land, although these documents did not protect them from being evicted.

A woman in her early 50s who belongs to the Ga family who settled in the area generations ago explains that she was born in the area and has been living there ever

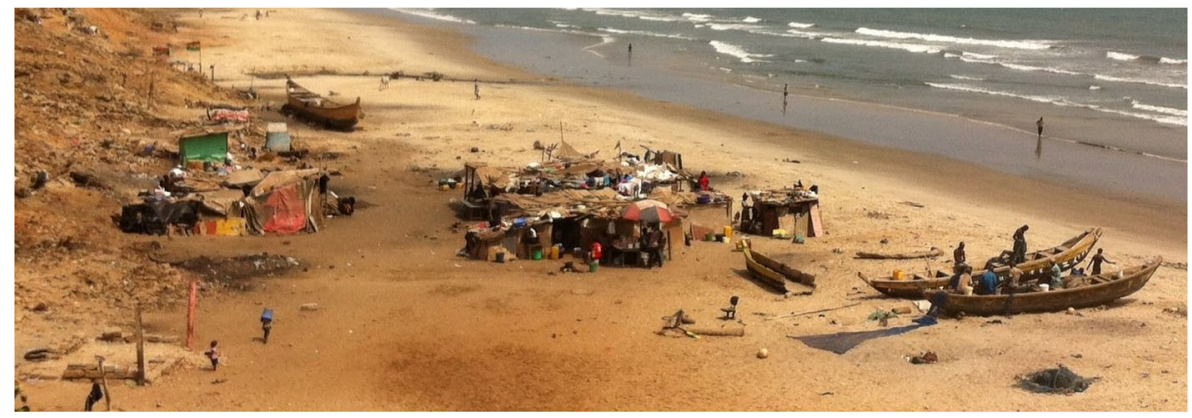

Fig. 1 Shelters in 'Down Town' Photo: Lena Fält 
since. Like her ancestors, this woman and her family make a living from fishing and she cannot imagine moving somewhere else; 'We were born here, so we cannot leave this place. Also, we work here.' (Interview 2015). The evicted community, however, did not only encompass Ga people. During the last few decades, Mensah Guinea has been attracting migrants from all over Ghana and other West African countries, and before the eviction took place the population was roughly made up of two groups: first, the Ga people making a living from fishing; and secondly, the 'migrants' who mainly made their living through petty trade. The cost for renting or building a house or room in Mensah Guinea used to be low, and this was one of the main reasons for settling in the area according to the respondents. Also, the geographical location explains why people settled in this place. The fishermen and fishmongers are dependent on the proximity to the sea, and the place-specific knowledge of the fishing water outside Mensah Guinea, which has been passed on from generation to generation, makes this particular beach location especially valuable. Also, for the other group, the petty traders, the location was of great importance to their livelihoods. Makola market, Accra's largest marketplace, can be reached on foot from Mensah Guinea, and hence wholesale agents and good trading locations were found nearby, which saved the traders time and money. The settlement itself was also seen as a good place for trading, as one woman relates: 'This place, when you are trading, this place is like a business place. Before, when people were living here, anything that you sell they buy it, quickly, and you get something small to save, and some to feed yourself' (Interview 2015) (Fig. 2).

The former inhabitants of Mensah Guinea remember the area as a well-functioning community with a mixed population in a good location. However, they are also aware of the bad reputation that the area had, but forcefully contest descriptions that characterise the area as a place of violence, prostitution and criminality. A young woman explains: 'Here it is peaceful, there are no burglars around and prostitution and others things here, if they say such things they are lying' (Interview 2015). In terms of infrastructure and services, the community had access to piped water, electricity, a kindergarten/school run

Central Accra

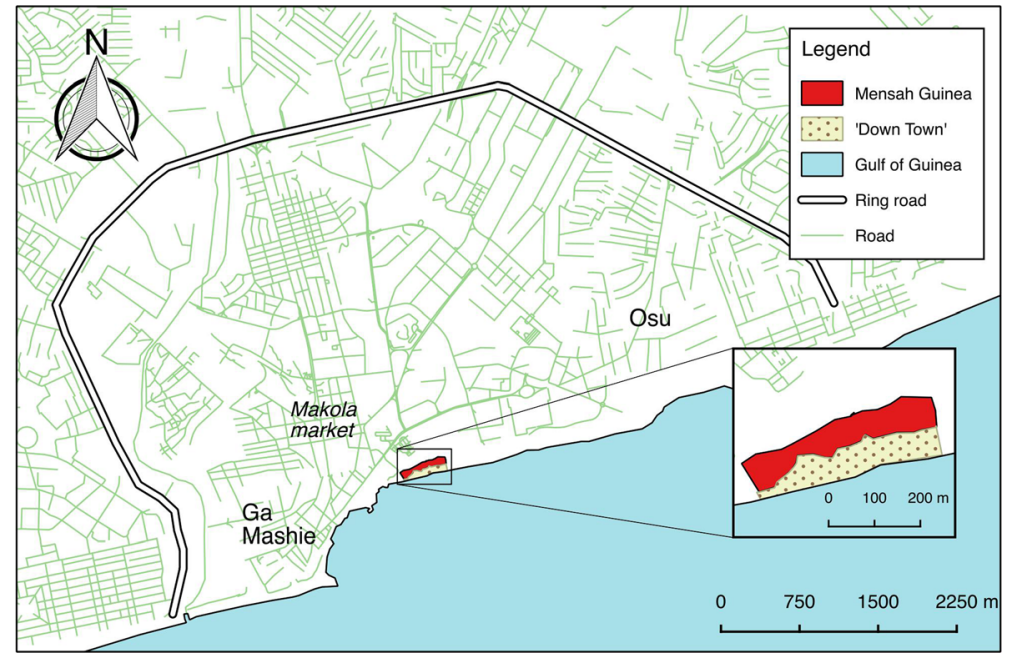

Fig. 2 Location of Mensah Guinea and 'Down Town' 
by a local church, public toilets and bath houses. At times, however, these services did not work properly and therefore some hesitated to recommend the area to family and friends. A woman who lived in the area for about ten years' states:

Even though we like here, we do not like here because of the gutter and other things, and the water. The water is a kind of water that is not neat, and this is not a place that you can tell your sister or brother to come and stay with you. If you are staying here, you know you are staying here because of work. (Interview 2015)

The non-partisan-elected assembly member who represents the area in the local government, as part of a larger territory, is of a similar opinion. He states that Mensah Guinea had problems with the gutters and describes the area as 'a slummy place' where 'people had put up their buildings haphazardly' (Interview 2015). However, he also argues that the community was willing to improve the area's physical structure and explains that the community started up a cleaning exercise as soon as they heard of the eviction plans:

When I heard the news I told them [the local government] they should wait for us, and show us what to do, so that we ourselves can do what they want us to do for them /.../. To upgrade it; where this structure is not good, just remove it, let us do this, let us do that, and we started before they came to demolish the place. (Ibid.)

This story is confirmed by the self-proclaimed community leader of Mensah Guinea who also emphasises that the inhabitants used to organise cleaning exercises on a regular basis. However, the local government did not change its mind despite the community's efforts to clean the area and its task force arrived with bulldozers, accompanied by the police, just 3 days after the eviction note had been distributed. Approximately 3000 people lost their homes during the demolition, and many also lost personal belongings. Moreover, the eviction ruined livelihood strategies for both petty traders and fishermen.

The former residents perceive the demolition as highly unjust in several regards. The Ga people claim that they have the right to stay in the area and refer to the approved building permits that they hold and their historical connections to the place. Hence, they condemn the exercise and state that they will eventually challenge it in court. The migrants, in contrast, are mainly upset over the short notice given and state that they attempted to postpone the exercise. One man explains: 'the elders went to the office to beg them [the local government] that they should give us like six months so that everybody will search for a place to go. They said no'. (Interview 2015). Despite the perceived unjust procedure of the local government, the community did not protest openly against the intervention. Some responded to the local state's appeal of not making the demolition a 'political issue'. A young lady explains: 'The reason why the people did not protest is because big men came to talk to us, the Accra chiefs and Vanderpuije [referring to the traditional leaders of the surrounding areas and the Mayor] came to inform us that we should not politicize the demolition exercise' (Interview 2015). According to the community leader, fear of the police who accompanied the bulldozers and lack of public support for the affected population also explain the 
absence of resistance: 'they fear that if they are arrested, who is coming to their aid? So that is all' (Interview 2015).

Following Watson's (2009a) conceptualisation of 'clashing rationalities', it is evident that the former residents of Mensah Guinea settled in this particular area based on 'a will to survive'. In a city where the majority of the population is excluded from both formal housing markets and 'regular and secure forms of income generation' (Ibid: 2268), Mensah Guinea offered affordable housing and place-specific income opportunities. However, the narratives of the former residents also demonstrate that the rationalities behind their stay in Mensah Guinea are more complex than simply striving to make ends meet on a daily basis. The Ga people claim their right to this land on the basis of their historical rooting in the area as well as by claiming legal rights to the land through land titles. Also, the relatively well-functioning auto-constructed infrastructures and services in Mensah Guinea point to the capability of the community to provide for itself, which in cities where the state is weak gives yet another rationality for settling in informal settlements. Furthermore, this case demonstrates that the people who used to live in Mensah Guinea were prepared to negotiate with local authorities and develop the area in line with the authorities' desire to 'clean-up' the place. Hence, spatial order and a hygienic environment-ideals based on dispositional and generative rationalities in Huxley's (2006) terminology — are understood as important also amongst this segment of the urban poor.

\section{Multiple Rationalities Behind the Eviction}

In the following section, the multiple arguments and agendas brought forward to justify the demolition by local and central state bodies, civil society actors and media are presented and analysed, with a focus on the spatial rationalities at play. The explanatory power of speculative urbanism and urban revanchism is also elaborated upon.

\section{Hygiene and Immoral Behaviour}

The decision to evict the people of Mensah Guinea was taken by the Mayor of Accra with support from several departmental heads in the local government, including the Director of Accra Town and Country Planning Office. The official motivation for the eviction was that cholera was spreading from this perceived 'unhygienic' neighbourhood, and therefore the government had to level the settlement to the ground. One of the physical planners in the city describes her experience of the community in these words:

I personally went there. We walked through before the demolition took place. I wanted to have a look at what was going on /.../ and it was horrible! Horrible! I'm telling you. /.../ No places of convenience so people were doing it anywhere, they don't have access to any water, nothing. So you could just imagine, the population there at that time if I'm not exaggerating could be more than 20000 . I am not too sure, but the people we saw there were so many. /.../ We found that many of the people who hawk on the streets, that is where they are sleeping and staying and the conditions were terrible. So the city said no, we cannot allow this to continue, so notices were served and then they were cleared. So that was it. 
Also, the Director of Accra Works, the department responsible for the implementation of urban plans, development control and maintenance of public spaces and buildings, emphasises that the lack of hygiene in the area justified the demolition:

There were a lot of health issues that were happening in this particular area. We had an outbreak of cholera, and cholera is a disease that is linked to unhygienic conditions. When you have people who despite all that is going on [the cholera outbreak] and despite all the education that we give them, still go back and prepare food in commercial quantities for sale to other people who are not aware of the conditions under which the food was prepared, then as a local government you have to sit up and make a decision ... there is no option.

These statements demonstrate how civil servants justify this demolition exercise by pointing to what they perceive to be unacceptable living conditions in the area, emphasising the health hazards for the city at large. However, neither alternative housing nor other compensation was offered to the former population and while the negative aspects of this living environment are highlighted, no attempts are made to provide healthier environments for the affected population. The Director of Works continues his description of Mensah Guinea by stating that the community 'has become a den for criminals, it has become an area where a whole lot of things, I mean bad things, go on. It's a no-go area at night; you cannot go there if you don't live there'. Similar words are used by the Director of Accra Town and Country Planning Office who describes Mensah Guinea as 'dirty, unhygienic, and the home of thieves and prostitutes'. These statements point to how the authorities in addition to the discourse on hygiene assign immoral behaviourtheft, prostitution and ignorance - to the inhabitants of this place in order to justify the demolition. The media also reproduces these discursive representations of Mensah Guinea as an unhygienic and immoral place. Ghana's two leading daily newspapers, the state-owned Daily Graphic and independent Daily Guide, together published 11 articles related to the demolition during August 2014. According to cultural anthropologist Jennifer Hasty (2005), the Daily Graphic functions as the state's extended arm:

Through a public rhetoric of state journalism grounded in the discourse of national development, journalists for the state press are rhetorically summoned into the hegemonic project of the state and positioned to reproduce its daily ceremonies of legitimacy and consensus. (p. 33)

In contrast, she continues, Ghana's independent press, including the Daily Guide, 'have been mobilized against the discursive regime of state news' (Ibid: 86). However, in the case of Mensah Guinea, these newspapers present similar stories. In both newspapers, Mensah Guinea is consistently referred to as a 'slum' built up of 'illegal structures' and the inhabitants are simply referred to as 'squatters'. The day the demolition exercise started, the Daily Guide reported that Mensah Guinea is 'labelled as one of the areas surrounded with filth' and noted that 'the area is being blamed for the recent cholera outbreak' (2014a). The following articles reproduce the hygiene 
discourse of the local authorities, and much effort is put into describing the perceived unsanitary conditions of the area:

Their bodies have built resistance over the years to the common diseases as they nightly lay their heads in a place where hygiene is a stranger; with rats and mice scampering for pieces of leftover food. That is not to say that they are totally immune to the ailments associated with the absence of basic hygiene. (Daily Guide 2014b)

These newspapers thus adhere to the understanding that the demolition of Mensah Guinea was necessary, based on the perceived negative impact that this physical environment has on the inhabitants' health and morals. Yet, the independent Daily Guide (2014a) also asked for a more 'human face' in future demolition exercises:

We appreciate the importance of taking drastic measures to hold at bay the mounting incidence of cholera, but these should be undertaken with a human face and a large dose of reasonableness.

Importantly however, the demolition itself is neither questioned nor problematised in these articles and none of the articles engage with the underlying political issues of the future direction of urban development in terms of urban land use, poverty, housing shortage or wealth redistribution. The quote above demonstrates that the media accept the official reason for the demolition - to counteract a cholera outbreak - as a reasonable justification for this type of intervention. This acceptance is anchored in the strong medico-biological generative rationality that the decision to demolish Mensah Guinea officially builds upon, which at least rhetorically links the status of physical environments with the health condition and morality of the people using that space. While medico-biological generative rationalities may be used to evoke upgrading of marginalised areas, for instance by improving water and sanitation facilities, the opposite happened in Mensah Guinea where the community was evicted without compensation or assistance. Hence, it is evident that the decision was underpinned by an aspiration not to assist but to remove unwanted, i.e. poor, environments (and people) from this centrally located part of the city, in resemblance to urban revanchism. However, this revanchist intervention was not only a replica of New York urban revanchism going global, as foreseen by Smith (2001), but a planning strategy drawing on anti-poor perceptions that have historical roots stretching back to colonial times. It is also important to emphasise that Ghana's national urban policy is not revanchist per se, in contrast to revanchist policy documents in other parts of the world.

\section{Urban Renewal-Dreams of Becoming a Tourism Magnet}

While the local government claims that the sanitary conditions were the reason behind the demolition of Mensah Guinea, the central government presents a different story. A senior official at the Ministry of Tourism, Culture and Creative Arts states that the parliament recently approved plans to transform Mensah Guinea and its surroundings into a high-class waterfront development for tourists: 
That is what we have indicated here; theme parks, hotels, night clubs, restaurants, a clinic, a football park, service apartments, children's amusement park. So that this area becomes a tourism enclave! (Interview 2015)

According to this new plan, Mensah Guinea and its surroundings will be transformed into a modern tourism destination consisting of luxury high-rises. The senior official states that the renewal of this area 'will make Accra', and he believes that this (re)development project will increase the city's attractiveness in a global perspective (Ibid.). Furthermore, he declares that the plan for a tourism enclave is incompatible with the now demolished settlement and acknowledges that the progress of the project partly explains the demolition exercise. Yet, he emphasises that the tourism enclave is a 'sustainable project' where consensus seeking is important:

So it is a question of bridging the gap, or bringing all these ideas of the people, and see how you can harmonize it and make sure that at the end of the day you are satisfying the interest of all stakeholders. What is the public interest? What is private sector interest? What is the tourist interest? What is the civil society interest? And what is the community interest? Because if you are not able to satisfy the interest of all these groups, and make them play a role, then the project will not be sustainable.

However, not surprisingly, the former inhabitants of Mensah Guinea have not been asked to participate in the preparation of the new plan, and participation seems to be restricted to groups that support the project.

The (re)development of this beach location will be fully financed by private investors, and while no agreements with real estate developers have been signed yet, the senior official is convinced that the central location will attract investors; 'everything is being generated from the land' (Ibid). To steer urban land use in accordance with market principles is generally accepted also by the planners at local government. With regard to Mensah Guinea, the Director of Works asks 'Why should we sit and let a prime land like a beach front be used for such a purpose [informal settlement]? You move them'. The traditional authorities also support the central government's vision of a more competitive Accra. The traditional chief of Osu, where Mensah Guinea is located, forcefully argues that Accra needs a 'facelift', which to him implies that poor neighbourhoods have to be removed from the central part of the city and ideally replaced with skyscrapers. The Paramount Chief of Osu explains: 'these sites [along the beach] are the most expensive areas /.../ so why should we use it for slums? For any meaningful development to come, definitely some people's lives would be affected' (Interview 2015). He further argues that the people of Mensah Guinea initially came 'from somewhere' and hence when they were 'removed from there [they] must definitely have somewhere to go' (Ibid). If the Paramount Chief had a mandate, he would replicate the displacement in the larger Osu area:

The reason why we brought in real estate is that when you look around, the buildings here are very old and Osu is in the centre of the city so we have plans for relocating everybody and putting up high-rise buildings here. (Ibid.) 
Yet, the ideas of transforming Mensah Guinea to a place for leisure are not new. Similar plans were prepared during the colonial era and later adopted by the newly independent state in 1958. The underlying rationalities and the target groups however differ fundamentally between these plans. While the newly independent state sought to develop this beach location into a recreational area for the inhabitants of Accra, the present day administration, in contrast, seeks to develop a fenced enclave that will attract international investment and tourism and simultaneously exclude most ordinary citizens. Hence, the old plans resemble vitalist rationalities aiming to create a 'modern developed city' that would benefit the 'social whole', while the new plan heavily relies on rationalities based on market logics and ideals of orderly urban aesthetics that will benefit only a few inhabitants. The contemporary (re)development plan exemplifies the process of 'accumulation by dispossession' since the displacement will make room for profit-making real estate and commercial activities on this piece of land. In this respect, it also resembles speculative urbanism since the project is based on speculations on how to make a profit from this piece of land through real estate, with a high degree of government involvement. However, the scale of this project is rather small in comparison to the urban (re)development corridors of India that the concept of speculative urbanism first sought to capture. It is also worth noting that the actors behind speculative practices in Ghana are somewhat different from those of India, while the state is heavily involved in both contexts-there is no equivalent in Accra to the prominent IT sector that heavily informs the development of Bangalore. Hence, while the concept of speculative urbanism does point to important dimensions of speculative capital accumulation processes that are present in urban Ghana, more research is needed to assess the scale and intensity of these speculative practices.

\section{Spatial Order $=$ Development?}

While the official reason for the demolition was to stop the cholera outbreak, the section above demonstrates that the (re)development plan for the area also played an important role. Additionally, this case study illustrates that a more general desire to achieve spatial order prevails in Accra, which adds to the rationalities behind the demolition of Mensah Guinea. As explained earlier, the aspiration for an orderly urban environment is clearly expressed in both legislation and Ghana's national urban policy. Furthermore, a strong discursive coupling is made between 'development' and spatial order and/or spatial planning, by politicians, civil servants, local NGOs and the international community (with the World Bank at the forefront). The physical appearance of the city is at the heart of this discourse on spatial order, and the Director of Town and Country Planning in Accra explains that the main priority for the future development of Accra is to raise the skyline of the city since 'high rises are what makes a city a city' (Interview 2014). In similar ways of thinking, a top priority of the Mayor is 'the beautification of the city' according to a local leader of the ruling party National Democratic Congress. He explains that the Mayor's beautification agenda involves: 
...changing the facial appearance of the city: like putting up buildings that will change the face of the city; designing say parks and other lanes to make it look modern or nicer and building neat schools. (Ibid.)

Similar ways of reasoning are ever present when different challenges of rapid urbanisation - such as urban sprawl, lack of housing, unemployment and insufficient basic infrastructure - are discussed in Ghana. Spatial order and a neat environment are considered key factors for modern urban development, and this strong associative relationship between development and order makes it difficult to question planning-led interventions that seek spatial order since this would imply the questioning of development (cf. Ferguson 1994). The World Bank, for instance, emphasises that 'To meet the challenges of urbanisation today and tomorrow, Ghana will require much stronger spatial and land use planning and management in municipal and metropolitan areas' (World Bank 2014: 15). This mantra is reproduced during conferences and workshops ${ }^{2}$ on urban development in Accra where spatial planning is repeatedly presented as an instrument that can achieve 'international competitiveness', 'sustainability', 'resilience', 'SMART cities', 'affordable housing', 'reduction of poverty' and/or 'inclusivity'.

In a comment on the eviction of Mensah Guinea in the local news, a spokesman from local government assured that 'any activity that is inimical to the development of our capital city would not be tolerated' (www.spyghana.com 2014-09-10). This statement suggests that settlements like the one of Mensah Guinea are understood as the antithesis of development, and these settlements must be removed in order for Accra to develop, although no measures are taken to assist the affected population. By pointing to the need for development, this spokesman further explicitly urged the public not to make the demolition a 'political issue':

We want to state here that the development agenda of AMA [the local government] should not be trivialized and politicized Again the operations of the AMA require the honest and sincere support of all stakeholders to develop Accra. [sic] (Ibid.)

Perhaps a little surprisingly, also NGOs working with housing rights active in the capital are incorporated in this de-politicised line of thought regarding urban development. Despite the fatal consequences that the eviction of Mensah Guinea had on the community and its inhabitants, civil society remained silent. Amnesty International (2011) has a clear policy against forced evictions of people living in 'slums', which declares:

Irrespective of whether people are squatting or have legal title to the homes or land that they occupy, under international law, no evictions may be carried out without due process and basic legal protections. (p. 18)

However, when the Ghanaian office heard of the demolition of Mensah Guinea, they sent an administrator to the site and thereafter decided not to take action. Also, Housing

\footnotetext{
${ }^{2}$ Ghana National Urbanization conference 2014 and Cities Alliance Accra start-up workshop 2015 amongst other events
} 
the Masses, a local organisation that aims to 'cater for low income areas' and works with 'slum upgrading and prevention, low income housing, inclusive urban development and citizen's participation', in fact supports the demolition. The chairperson states:

I don't think anybody needs to be squatting there and littering the place and making the place dirty, no I don't think that is a good thing, it is not a good sign. (Interview 2015)

Yet, another relatively influential association in urban politics in Accra, the Ghana Federation of the Urban Poor, which is affiliated to the transnational network Slum Dwellers International, kept a low profile during and after the demolition of Mensah Guinea despite their newly adopted strong policy against evictions. The national leader states that the organisation did not have any members in this particular settlement and even though they went to the place during the eviction, they did not intervene since they thought it was 'too late' (Interview 2015). The national secretary adds that the Federation's non-presence in Mensah Guinea indicates that the community was 'weak' and thus lacked the means to protest against the intervention (Interview 2015). The only direct criticism of the demolition was put forward by the Slum Union, a relatively new grassroots movement that works to improve the living conditions in poor settlements across Ghana. The Slum Union claimed in local media that the demolition violated international conventions and stated that 'the relocation of persons who have stayed in a place for more than 20 years must be made as smooth as possible' (www.ghanaweb. com 2014). In similarity to the media coverage, this criticism is directed towards the execution of the demolition, while the exercise itself is not questioned.

The lack of resistance to the eviction - or the 'pre-requisites of acceptance' in Rose and Miller's (1992) words - most probably have multiple explanations. However, it partly seems to be linked to the strong dispositional rationality that connects development and an orderly urban aesthetics and further depicts planning as a much needed technical solution to the complex problems related to rapid urbanisation. In addition, anti-poor revanchist attitudes that blame the urban poor for their marginalised position in society are also anchored amongst civil society actors. Few actors in society seem to question these 'truth claims' on desirable urban development, which implies that the actual practices of urban planning, including its rationalities, strategies, techniques and goals, are seldom debated. Important political questions about what kind of city is desirable, and who will benefit and not by dominant city visions and planning practices, hence seem to be absent from the public discussion.

\section{Conclusion}

In this paper, I have explored the spatial rationalities that inform contemporary processes of urban transformation in Accra through a case study of the displacement of the informal settlement Mensah Guinea. The paper shows that market-driven rationalities played an important role in the justification of this urban intervention and the concepts of urban revanchism and speculative urbanism are useful heuristics in the analysis of how the strive for capital accumulation, in combination with anti-poor attitudes and land speculation, informs contemporary urban change and creates new 
patterns of socio-spatial inequality in this West African urban context. Importantly, however, these concepts do not fully capture the complex interplay of the multiple rationalities that were used in the justification of the displacement of Mensah, hence this paper stresses that also non-market-driven rationalities must be incorporated in the analysis of contemporary urban change across the African continent. Drawing on Huxley's typology of dispositional, generative and vitalist rationalities, which represent socially produced knowledge bases that emphasise (1) the benefits of spatial order, (2) the links between the physical environment and human wellbeing and morality and (3) different strategies for development of the 'social whole', I demonstrate that multiple actors and rationalities engage in contemporary processes of physical, social and economic restructuring of central Accra. Intertwined with market-driven rationalities, specific ideas on the benefits of 'spatial order' and how to protect public health through interventions in the physical environment were used to legitimise the eviction of Mensah Guinea.

Officially, the local state uses a strong generative spatial rationality to justify the eviction of Mensah Guinea and argues that the intervention was necessary in order to stop the cholera outbreak in the city at this time. Connected to this postulation of the causality between hygiene and the physical environment, city authorities also assign immoral behaviour - theft, prostitution and ignorance - to the inhabitants of Mensah Guinea in order to justify the demolition. As the historical review demonstrates, this generative rationality is not new but has been used in Ghanaian urban planning circles since colonial times. Other rationalities also influenced the decision to displace Mensah Guinea. Based on ideas of 'modern' urban aesthetics, and rationalities that conceive market-driven land use planning to be the most efficient, the central state aspires to make Accra globally 'competitive' through the development of a luxury tourism enclave on the land of Mensah Guinea, a project supported also by the local government and traditional authorities. This (re)development scheme exemplifies what Harvey refers to as 'accumulation by dispossession' since the displacement of Mensah Guinea will make room for more 'profitable' land uses and simultaneously increase the international 'competitiveness' of Accra, according to state bodies and traditional authorities. Since this (re)development project is based on land speculation, it also demonstrates that the concept of speculative urbanism points to an important dimension of contemporary urban transformation in Accra and, most likely, African urban (re)development in general. Compared to the historical plans for transforming Mensah Guinea into a public space for leisure, speculation on the (future) exchange value of the land is now what drives the (re)development of this centrally located piece of land, and to promote private real estate on state-owned land is indeed a new take on urban development in this context. However, the speed, scale and intensity of speculative urbanism in Accra is still modest, at least in comparison to the development of speculative urban corridors in India, and caution must therefore be taken before urban development in Accra can be referred to as a fully fledged example of speculative urbanism.

In some respects, the demolition of Mensah Guinea also resonates with urban revanchism. The short notice of the eviction, the threat of violence during the exercise, the patronising comments about the area and its inhabitants during and after the demolition and not least the non-existent compensation to the affected people reveal the anti-poor agenda of this exercise. Also, the future (re)development plan indicates that the desire for certain urban aesthetics and functions is prioritised over the 
livelihoods of the urban poor, in accordance with revanchist urbanism. However, in contrast to the zero-tolerance policy in New York and the urban renewal program in Quito, Ghana's national urban policy and the development goals of Accra are not revanchist per se. In contrast, these documents emphasise the importance of improving the livelihoods of the urban poor as part of a broad development agenda that builds upon vitalist spatial rationalities, even though the complementary goals of urban beautification and spatial order seem to open up for revanchist interventions. A historical contextualisation also indicates that contemporary revanchist practices are linked not only to global neoliberal politics, as presented by revanchist theory, but also to colonial and post-colonial urban planning practices.

The analysis of the former resident's narratives about Mensah Guinea and the eviction of the settlement further demonstrates that this displacement is illustrative of what Watson terms clashing rationalities between logics of urban everyday life and city authorities' visions. To the former residents of Mensah Guinea, the community represented a place of opportunities in terms of livelihood strategies, sociability and affordable housing. Their decision to settle there was hence based on a strong rationality of survival, yet it was also influenced by historical connections to the place and perceived legal rights of occupancy. The state apparatus, in contrast, perceives Mensah Guinea to be 'out of place' and justifies the eviction despite Ghana's newly adopted national urban policy that explicitly seeks to improve the situation of the urban poor. Hence, the needs and desires of marginalised urban groups - such as the former residents of Mensah Guinea - are in practice ignored by state bodies on the basis of multiple converging spatial rationalities. Moreover, the displacement received almost no criticism in public and this study indicates that news media and civil society actors' perceptions on desirable urban development in Ghana rely on a strong dispositional rationality, which at least partly explain the lack of resistance to this intervention. To understand the clashing rationalities at play in African urban politics, it is thus important to pay attention to the numerous rationalities and actors engaged in the (re)making of urban space, and the power relations between them. Hence, also the spatial rationalities of non-state actors are important to include in the analysis of new directions of urban transformation in Africa.

In sum, the case of Mensah Guinea demonstrates that both state and non-state actors, active at different geographical scales, engage in the (re)production of generative, dispositional and market-driven spatial rationalities - rooted in the local urban policy context and influenced by globally circulating urban ideals - that justify and make acceptable forced evictions, ignoring the needs and desires of the urban poor and neglecting important political questions of who the city now is being (re)built for.

Acknowledgments I would like to thank Andrew Byerley, Ilda Lindell and the anonymous reviewers for valuable comments on earlier drafts of this paper. I would also like to thank Peter Mensah for invaluable assistance during the fieldwork.

\section{Compliance with ethical standards}

Funding The fieldwork has been carried out with financial support from Stiftelsen Elisabeth och Herman Rhodins minne, SSAG and Carl Mannerfelts fund.

Conflict of interest The author declares that there is no conflict of interest. 
Open Access This article is distributed under the terms of the Creative Commons Attribution 4.0 International License (http://creativecommons.org/licenses/by/4.0/), which permits unrestricted use, distribution, and reproduction in any medium, provided you give appropriate credit to the original author(s) and the source, provide a link to the Creative Commons license, and indicate if changes were made.

\section{References}

Accra Metropolitan Assembly. (2014). Focus areas for Accra Metropolitan Assembly (Action Plan 2014).

Afenah, A. (2012). Engineering a millennium city in Accra, Ghana: the Old Fadama intractable issue. Urban Forum, 23, 527-540.

Amnesty International. (2011). (Stop forced evictions. Protect people living in slums. London: Amnesty International Publications.

Appadurai, A. (2001). Deep democracy: urban governmentality and the horizon of politics. Environment and Urbanization, 13(2), 23-43.

Bakker, K., Kooy, M., Shofiani, N. E., \& Martijn, E. J. (2008). Governance failure: rethinking the institutional dimensions of urban water supply to poor households. World Development, 36(10), 1891-1915.

Byerley, A. (forthcoming). Drawing white elephants in Africa; re-contextualizing Ernst May's Kampala Plans in relation to the fraught political realities of late-colonial rule in Uganda. Planning Perspectives.

Daily Guide. (2014a). AMA renders squatters homeless. September 6.

Daily Guide. (2014b). Face-saving demolition. September 6.

Dickson, K. B. (1969). A historical geography of Ghana. London: Cambridge University Press.

Elden, S. (2007). Governmentality, calculation, territory. Environment and Planning D: Society and Space, 25(3), 562-580.

England, K. (2006). Producing feminist geographies: theory, methodologies and research strategies. In S. Aitken \& G. Valentine (Eds.), Approaches to human geography (pp. 286-297). London: SAGE.

Ferguson, J. (1994). The anti-politics machine: "development," depoliticization, and bureaucratic power in Lesotho. Revision of the author's thesis (Ph.D.). Harvard University: Minneapolis.

Flint, J. (2002). Social housing agencies and the governance of anti-social behaviour. Housing Studies, 17(4), $619-637$.

Flyvbjerg, B. (1998). Rationality and power: democracy in practice. Chicago: University of Chicago press.

Flyvbjerg, B. (2006). Five misunderstandings about case-study research. Qualitative Inquiry, 12(2), $219-245$.

Foucault, M. (2007). Security, territory, population: lectures at the Collège de France, 1977-78. Basingstoke: Palgrave Macmillan.

Goldman, M. (2011). Speculative urbanism and the making of the next world city. International Journal of Urban and Regional Research, 35(3), 555-581.

Government of Ghana. (1945). CAP 84. Town and Country Planning Act. Government of Ghana.

Government of Ghana. (1993). Act 462. Local Government Act. Government of Ghana.

Government of Ghana, Ministry of Housing. (1958). Accra, a plan for the town; the report for the Ministry of Housing. Accra: Government printing.

Government of Ghana, Ministry of Local Government and Rural Development. (2012). National Urban Policy Framework. Government of Ghana.

Harvey, D. (2007). Neoliberalism as creative destruction. The Annals of the American Academy, 610, $22-43$.

Hasty, J. (2005). Press and political culture in Ghana. Bloomington: Indiana University Press.

Huxley, M. (2006). Spatial rationalities: order, environment, evolution and government. Social \& Cultural Geography, 7(5), 771-787.

Huxley. (2007). Geographies of governmentality. In J. W. Crampton \& S. Elden (Eds.), Space, knowledge and power: Foucault and geography (pp. 185-204). Aldershot: Ashgate.

Huxley, M. (2008). Space and government: governmentality and geography. Geography Compass, 2(5), $1635-1658$.

Kamete, A. Y. (2013). Missing the point? Urban planning and the normalisation of 'pathological'spaces in southern Africa. Transactions of the Institute of British Geographers, 38(4), 639-651.

Konadu-Agyemang, K. (2001). The political economy of housing and urban development in Africa: Ghana's experience from colonial times to 1998. Westport: Praeger.

Larbi, W. O. (1996). Spatial planning and urban fragmentation in Accra. Third World Planning Review, 18(2), $193-215$. 
Larbi, W. O., Antwi, A., \& Olomolaiye, P. (2004). Compulsory land acquisition in Ghana-policy and praxis. Land Use Policy, 21, 115-127.

Legg, S. (2006). Governmentality, congestion and calculation in colonial Delhi. Social \& Cultural Geography, 7(5), 709-729.

Lindell, I. (2008). The multiple sites of urban governance: insights from an African city. Urban Studies, 45(9), 1879-1901.

Mackie, P. K., Bromley, R. D., \& Brown, A. (2014). Informal traders and the battlegrounds of revanchism in Cusco, Peru. International Journal of Urban and Regional Research, 38(5), 1884-1903.

MacLeod, G. (2002). From urban entrepreneurialism to a "revanchist city"? On the spatial injustices of Glasgow's Renaissance. Antipode, 34, 602-624.

Miraftab, F. (2007). Governing post apartheid spatiality: implementing city improvement districts in Cape Town. Antipode, 39(4), 602-626.

Mohindra, K. S., \& Schreker, T. (2012). From bulldozing to housing rights: reducing vulnerability and improving health in African slums. Global Health Promotion, 20(1), 64-69.

Myers, G. (2015). A world-class city-region? Envisioning the Nairobi of 2013. American Behavioral Scientist, 59(3), 328-346.

Njoh, A. J. (2003). Urbanization and development in sub-Saharan Africa. Cities, 20(3), 167-174.

Parnell, S., \& Robinson, J. (2006). Development and urban policy: Johannesburg's city development strategy. Urban Studies, 43(2), 337-355.

Pieterse, E. (2008). City futures: confronting the crisis of urban development. London: Zed.

Pieterse, E. (2010). Cityness and African urban development. Urban Forum, 21(3), 205-219.

Rabinow, P. (1989). French modern: norms and forms of the social environment. Cambridge: MIT Press.

Robinson, J. (2006). Ordinary cities: between modernity and development. London: Routledge.

Rose, N., \& Miller, P. (1992). Political power beyond the state: problematics of government. British journal of sociology, 1, 173-205.

Smith, N. (2001). Global social cleansing: postliberal revanchism and the export of zero tolerance. Social Justice, 28(3), 68-74.

Smith, N. (2002). New globalism, new urbanism: gentrification as global urban strategy. Antipode, 34(3), 427-450.

Swanson, K. (2007). Revanchist urbanism heads south: the regulation of indigenous beggars and street vendors in Ecuador. Antipode, 39, 708-728.

Turner, S., \& Schoenberger, L. (2012). Street vendor livelihoods and everyday politics in Hanoi, Vietnam: the seeds of a diverse economy? Urban Studies, 49(5), 1027-1044.

United Nations. (2014). Forced evictions. Fact Sheet No. 25/Rev.1 New York \& Geneva: United Nations.

Van Synghel, K., \& de Boeck, F. (2013). Bylex's tourist city: a reflection on Utopia in the post-political city. In E. Pieterse \& A. Simone (Eds.), Rogue urbanism: emergent African cities (pp. 83-89). African Centre for Cities: University of Cape Town.

Watson, V. (2009a). Seeing from the South: refocusing urban planning on the globe's central urban issues. Urban Studies, 46(11), 2259-2275.

Watson, V. (2009b). 'The planned city sweeps the poor away...': urban planning and 21st century urbanisation. Progress in Planning, 72(3), 151-193.

Watson, V. (2014). African urban fantasies: dreams or nightmares? Environment and Urbanization, 26(1), 215-231.

World Bank. (2014). Ghana urbanization review. Phase 1 report. Final draft-May 2014. 